DOI:10.17951/h.2019.53.2.67-77

\begin{tabular}{lc}
\hline & A N N A L E S \\
UNIVERSITATIS MARIAE CURIE-SKŁODOWSKA \\
LUBLIN - POLONIA \\
SOL. LIII, 2
\end{tabular}

\author{
BEATA REFORMAT \\ beata.reformat@ue.katowice.pl \\ University of Economics in Katowice, Department of Marketing, \\ ul. 1 Maja 50, 40-287 Katowice, Poland \\ ORCID ID: https://orcid.org/0000-0002-4178-9541
}

\title{
The increased importance of geolocation in retail trade in Poland- selected aspects of activities
}

Keywords: geolocation; marketing communication; retail trade

JEL: O33; L81; L86

How to quote this paper: Reformat, B. (2019). The increased importance of geolocation in retail trade in Poland - selected aspects of activities. Annales Universitatis Mariae Curie-Skłodowska, sectio H - Oeconomia, Vol. 53, No. 2.

\begin{abstract}
The article presents geolocation as a modern form of communication with consumers, which is based on new methods of sending information. This modern technological solution is increasingly used by enterprises in various industries, including retail entities. It has a very wide range of applications from the perspective of marketing activities of trade entities. Geolocation can be used in the process of the analysis, planning and implementation of the marketing activities accompanying market research, the segmentation process or the composition of marketing mix tools. The article applies secondary research in the form of a critical analysis of the literature, including the analysis of activities of selected entities who are leaders in the application of geolocation.
\end{abstract}

\section{Introduction}

In recent years we have seen an increase in the importance of marketing activities among Polish retailers based on geolocation, which is a modern form of communication with consumers. It is useful for the identification of customers' features, 
the recognition of their needs in real time, offering new products and services, and strengthening customers' loyalty. The opportunities it offers can be applied by retail trade shops. These entities are cooperating increasingly frequently in this sphere to provide mutual advantages.

Geolocation, which refers to the determination of location through a mobile phone, is also becoming increasingly popular in Poland. Strong competition is forcing stores to start applying this innovative technology to maintain current customers and acquire new ones. The scope of its application is influenced by many factors. Determinants that favour the development of geolocation in Poland include the increasing number of smartphones and Wi-Fi hotspots, and growth in the recognisability and use of geolocation applications. It is a new challenge for Polish retailers.

The first part of the paper presents the essence of geolocation and its functionality in the context of its most important benefits and the areas of its application. The grounds for the application of these solutions as well as the determinants favouring and hindering the application of geolocation in Polish conditions are outlined. The second part describes examples of the use of this tool in the retail trade in Poland.

\section{Definition of geolocation and its functionality}

Geolocation is the process of finding, determining and providing the exact location of a device on a map thanks to its geographical coordinates and measurements. It is generally used in a variety of applications to help locate human users (Dubos-Le Cadre, 2016, p. 10). According to Kieżel and Reformat (2015, p. 1), geolocation is a marketing innovation in the sphere of communication associated with technological and process innovation, consisting of new methods of information transfer. It is a solution increasingly more often applied by enterprises from various trades, including retail trade entities (Kern, 2018, pp. 21-22).

The use of geolocation is now available inside stores (indoor positioning system). For retailers, it represents new sales opportunities and a way to strengthen their relationship with their customers. Geolocation allows for the determination of the geographic location of people or things, usually with the use of the GPS or IP address of the device, for example, a mobile phone or a tablet computer (Triukose et al., 2012, pp. 158a-167; Notomi et al., 2015, pp. 38-41; Komosny et al., 2017, pp. 333-344). To establish location, geographic coordinates or address data, the post code, city or street, for example, are used. It can also be done on the basis of the visibility of other objects of known position, for example, base stations via mobile phone or Wi-Fi routers (Kang et al., 2015, pp. 210-217).

IP geolocation technology has a wide range of applications and requirements as its basis. For instance, after obtaining the geographical location of users with IP geolocation, the Internet service providers (ISP) can present their offers. It is worth adding that many online services will benefit from knowing the geographical locations of 
their users. From the perspective of the marketing activity of trade enterprises, this modern technological solution has a very wide spectrum of applications (Kucharska, 2013, pp. 110-111; Taylor \& Levin, 2014, pp. 759-760).

Geolocation can be applied in the process of the analysis, planning and implementation of marketing activities accompanying market research, the process of segmentation or the composition of marketing-mix tools. This is a perfect instrument for collecting information about the buying habits of consumers, shopping places preferred by them or tracking their typical "routes" (Coy, 2014, pp. 78-85; Reformat, 2017, p. 2127).

The possibility to present information that is interesting for a particular person and that depends on location and his or her features and preferences (e.g. a part of a map or advertising news from the area nearby) is one of the important functionalities offered by geolocation, which enables an offer to be directed at target segments (Kieżel \& Reformat, 2015, pp. 2-3). Moreover, geolocation also makes it easy to find a route between two places or an address (e.g. city, street and building number) using geographic coordinates. With the knowledge of the consumer's location, retailers can make decisions and communication activities in the sphere of sales, distribution and customer service in a more effective and efficient way. This information has to be exploited by retailers in order to stay competitive and to enhance the customer experience and operational efficiency (Deloitte, 2018, pp. 27-29).

Geolocation-based solutions are developing in Poland very quickly and in a diversified manner (McKinsey, 2016; Pearson, 2016; Frant, 2018, pp. 190-192). This is demonstrated, for example, by the implementation of the global positioning system (GPS), which is a system that determines the location of people or things in large buildings (Dubos-Le Cadre, 2016, p. 10). The actions of retailers based on geolocation involve the use of applications which offer discounts, promotions and attractive offers (H\&M, Reserved, Starbucks, Sfinks, C\&A and others), and also small and local businesses (e.g. in the service or gastronomy industries). The major advantages of these applications include the possibility of precisely reaching a particular user, their convenience and also their speed of reaction.

\section{Examples of the use of geolocation by retailers in Poland}

\subsection{QR code and mCoupons}

The application of geolocation by retailers is a combination of promotional activities and consumer activity. Mails, SMS and MMS messages are mainly used here. This is why geolocation is one of the most frequently used functions of smartphones and tablets (Reformat, 2016, p. 47). While logging into the application, a particular person receives notifications concerning current commercial, service and promotional offer in the places nearby. Information is displayed in a synthetic way; the user does 
not need to look through web pages but the entirety of the communication is visible simply by scrolling through the content of the screen.

Some types of software allow for sending promotional codes $(\mathrm{QR})$ or discount vouchers to customers that authorise them to make a promotional purchase. A QR code is a small square dot matrix barcode that can be captured by the camera of a mobile phone and then decoded by software on the phone, known as a QR code reader, to execute specific tasks (Cata et al., 2013, pp. 1-7) (Figure 1).
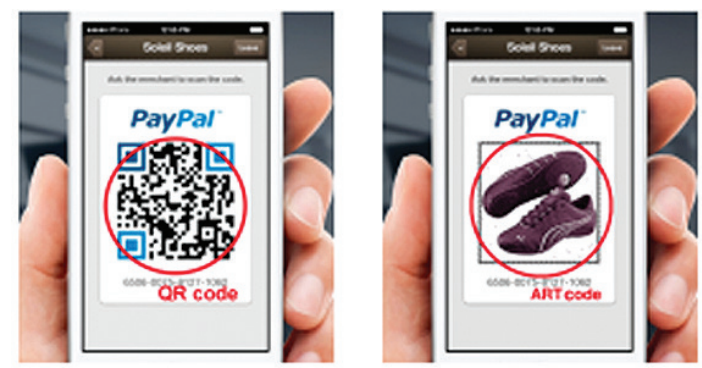

Figure 1. Example of QR code

Source: (Jang et al., 2016, p. 13).

An innovative widespread practice of retailers in Poland involves smartphone applications that allow for the scanning of bar codes of products found on store shelves (Chwałek, 2014, p. 94; Malinowska, 2016, p. 47). As a result, customers can almost immediately find what others think about the products and gain access to the special price of the product, offered only with the downloaded application. For example, the clothing retailer H\&M is certainly well-versed in such mobile apps. The store has a dedicated website for both smartphone and tablet users, and they have run countless mobile ad campaigns designed to attract the attention of their target audience. Recently, the store has launched a multi-channel effort that combines print advertising with mobile and e-mail marketing.

A special form of promotion are QR codes, which allow you to make cheaper purchases by entering a generated character set when placing an order. For many stores, this is a popular incentive to get customers to come back for more products (Mazur \& Mazur, 2014, p. 196).

In practice, many retailers in Poland are encouraging new customers to subscribe to newsletters, and then by e-mail sending them a seasonal discount code encouraging them to visit the store and learn about the new offer. On the websites of various retailers, consumers can find the discount codes they are most interested in. By choosing from a rich list of proposals prepared by stores from various sectors, the consumer can choose those that will help him or her save on current purchases (Su et al., 2014, pp. 40-46).

An interesting form of implementing QR codes is provided by companies specialising in services. In this industry, the code entitles the customer, for example, to 
cheaper taxi travel or a meal with home delivery at a lower price. Discount codes have a definite date of use and because they are sometimes attached to customer purchases as a kind of gift, to use them you have to make it before the specified time. The QR code for all products priced by the retailer is a double profit for the customer, because he or she pays less due to the discount and then pays less again after entering the code. This extremely convenient form of promotion is found in many stores in Poland, so it does not matter what the customer wants to buy because in every assortment field, as well as in services, you can take advantage of such a discount (Figure 2).

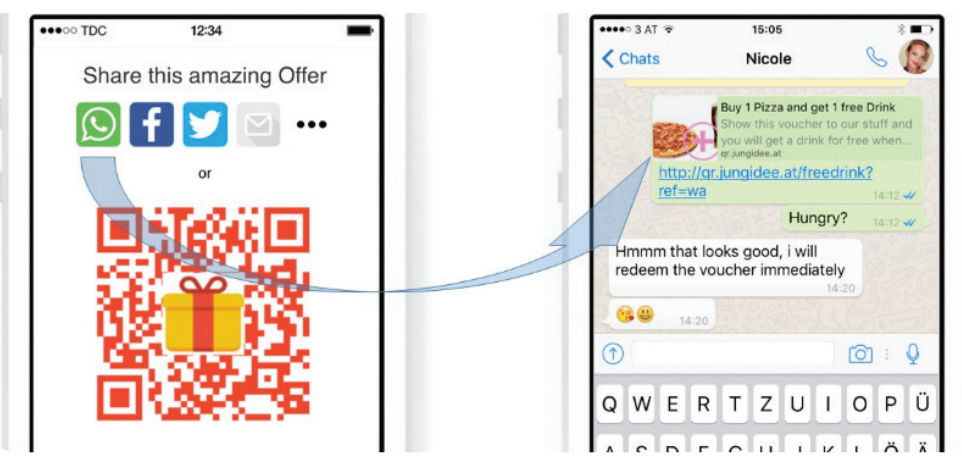

Figure 2. Example coupons (QR code)

Source: (How to create one-time..., 2018).

An alternative to QR Codes are mCoupons, which usually guarantee a certain amount that consumers can save by choosing to shop at a particular store. According to Fuchs et al. (2017, p. 327) the notion of an mCoupon represents specially prepared promotional information sent in the form of an SMS or MMS message to a specially selected, narrow group of recipients. Using the list of products or services prepared on the website, the customer does not have to buy what he does not need at the moment just to take advantage of the short-term discount. Having access to all codes and mCoupons on the Internet, he can choose only those that will interest him.

An important benefit of mCoupons is the lower amount that the customer will ultimately pay for selected products (Sławińska, 2016, p. 57). SMS or MMS messages are precise information carriers, thanks to which the moment at which a particular target group receives the promotional mCoupon that was sent can be precisely defined. Its determination is possible thanks to special T-Mobile transmitters, the so-called BTS (base transceiver station) (Barrile et al., 2009, pp. 775-784) (Figure 3). Thanks to them, the chance that the promotional offer will reach the group of recipients of interest for the sender and in their particular location is higher. The use of BTS in retail trade in Poland increases year on year. 


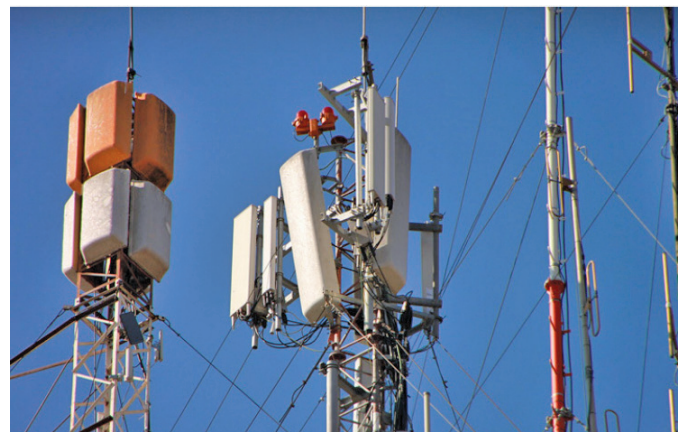

Figure 3. Base transceiver station (BTS)

Source: (Rozpoczęta się kampania ..., 2014).

Through mCoupons, interactions with consumer are enhanced (e.g. through their participation in a consumer lottery immediately after leaving the cash desk). This is because mCoupons allow a link to be placed in their message redirecting to a selected webpage. Thanks to such solutions, it is practically possible to involve the user and strengthen their interaction with a particular product, service or brand immediately.

The promotion offered by retailers in Poland using geolocation tools may have a different form, starting from a price discount on a selected assortment and ending with a specific amount which is deducted from the purchase of the entered code. These amounts are different and depend on the range of the store. This convenient form of promotion is found in many stores in Poland, so it does not matter what the customer wants to buy because in every assortment field, as well as in services, you can take advantage of such a discount.

\subsection{Augmented reality in trade retail}

Another important option for the retailers in Poland is the technology based on Augmented Reality (AR). AR is a way to increase the current perception of reality through generated computer stimuli, such as sound, video or graphics. Information appears as an "overlay" to the real world - we see it through webcam, smartphone, tablet, etc. (Malinowska, 2016, pp. 47-48). Using this advanced technology, consumers can now "virtually touch" or at least experience digital 3D visualisation of the product in the real environment without leaving home.

AR has practical applications in many retail sectors (clothing, gardening, cosmetology, automotive sectors, furniture, etc.). This technology encourages consumers to buy more through their mobile phones and tablets, and reduces the need to visit the store and wait for delivery to actually view the product in the intended environment. For example, a customer interested in professional furniture for his apartment can, by scanning his interior using a smartphone or tablet, send his photo to a qualified 
interior designer who chooses from the store's assortment all the equipment and "arranges" his individual rooms with 3D models of furniture in 1:1 scale. Using this modern mobile application, the client can check how the piece of furniture fits into their entire interior. All they have to do is drag the 3D model with their finger on the screen of their phone or tablet (Figure 4).

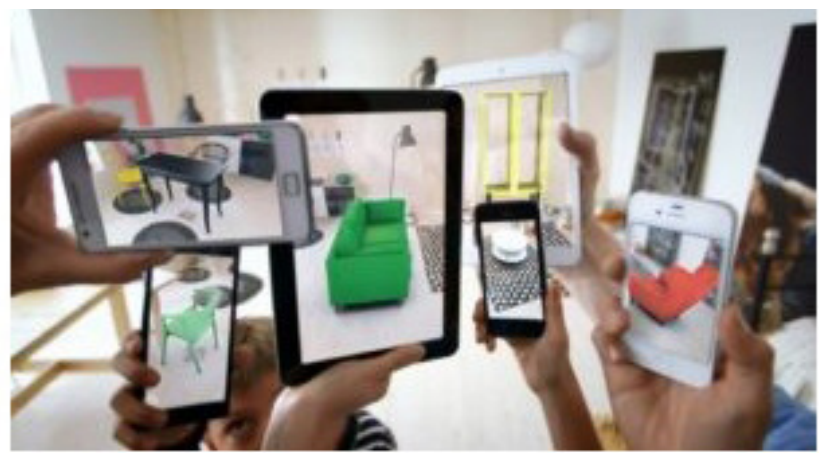

Figure 4. AR and its application in the furniture sector

Source: (Wallace, 2018).

The opportunity to see the furnished interior of the apartment makes it easier for the customer to make the right decisions related to his device. This is an important benefit for consumers but also for sellers who, thanks to this technology, see a drastic fall in the returns of purchases made by customers. At the same time, satisfying this type of innovative consumer need should be considered a significant challenge for retailers in Poland. A well-known example of AR in retail is the "IKEA Place" application (Figure 5).

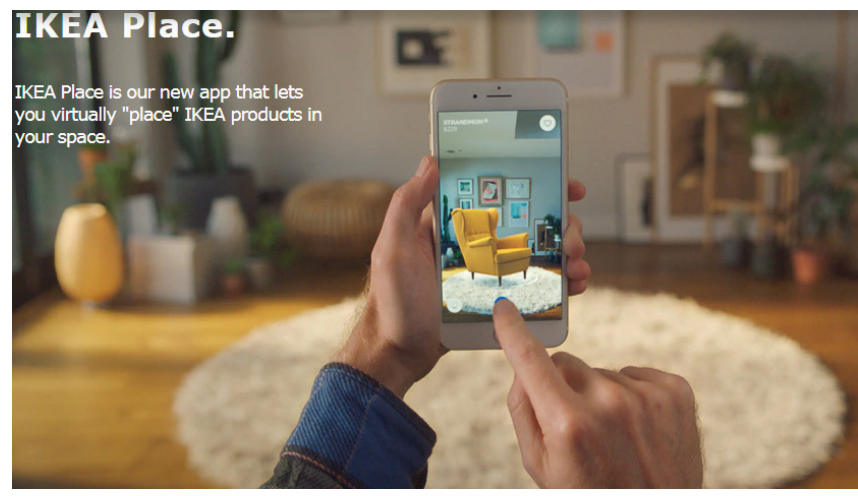

Figure 5. Example of the "IKEA Place" application available in the App Store 
Thanks to this application, customers can place three-dimensional models of more than 3,200 pieces of furniture in their homes (Plummer, 2018).

Nowadays, many shops in Poland offer similar opportunities to try out products using AR. For example, since 2014, L'Oreal drugstores have had the "Makeup Genius" App (Figure 6).

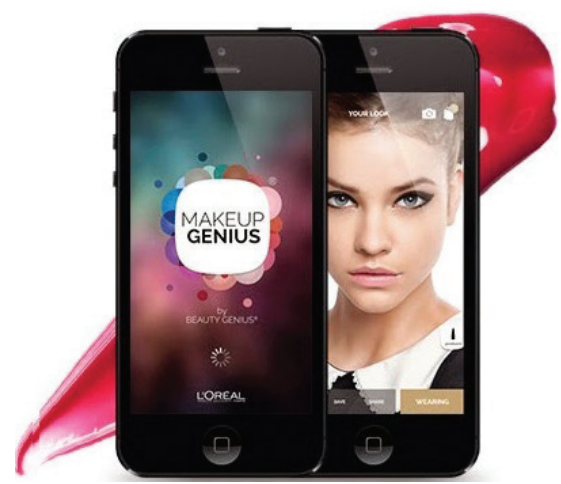

Figure 6. New application of L'Oreal stores “Makeup Genius” App

Source: (Nowa aplikacja L'Oreal..., 2014).

Through this new application, customers can see the effect of different cosmetics before buying. This allows consumers to see what a cosmetic looks like after application. It is also possible to purchase a selected product directly from the application level (Nowa aplikacja L'Oreal..., 2014).

The examples presented in the article only address the selected aspects of activities that exploit the potential of geolocation, but their analysis indicates that they constitute extremely useful innovations in the retail trade.

\section{Conclusions}

In summary, it should be noted that the challenges in using geolocation in Poland enable retailers to clearly distinguish themselves with the offer on the market, more precise access to customers, the personalisation of messages and establishment of long-term relationships with the customers. Geolocation enables the presentation of commercial offers to consumers in the right place and at the right time, which constitutes their fundamental advantage and benefit. Thanks to this, they are gaining increasingly more interest in Poland. From the marketing perspective, Poles use geolocation tools mainly for the purpose of searching for store offers and service providers, which enables them to find discounts and compare offers.

Information and communication technologies, including geolocation are becoming a determinant of modern retail trade and a way to reach the customer more 
effectively. This is being facilitated by dedicated mobile applications with appropriate software, which enable interaction with customers. Thanks to this, consumers have the opportunity to broaden their knowledge, share it and promote it in their environment.

With knowledge of the broadly understood consumer location, retailers can make decisions and communicate in the area of sales, distribution and customer service in a more effective and efficient way. It is of help in the following areas:

- analysis of demand and competition;

- use of micro-geographic criterion in the process of segmentation and creation of profiles of buyers' segments;

- analysis of consumers' behaviours in a particular area;

- analysis of buying habits and their movement, e.g. between stores in shopping centres;

- finding and selection of customers in particular areas;

- optimisation of the network of middlemen;

- rationalisation of distribution channels;

- making decisions about the location of a new commercial outpost;

- intensification of movement in a retail store;

- stimulation of sales (e.g. special discounts for people who go past a particular shop);

- planning digital advertising campaigns;

- optimisation of loyalty programmes (e.g. bonus discount vouchers for the most loyal customers).

It follows from the above that the use of geolocation by retailers has many advantages. It should be noted, however, that many consumers in Poland, especially older ones, do not have sufficient knowledge to use geolocation services and often also do not have the motivation to learn to use them, which leads to self-exclusion ("it's not for me"). It is worthwhile to discuss this issue and address the following question: What should be done to change this situation in the near future?

\section{References}

Barrile, V., Armocida, G., \& Bilotta, G. (2009). GIS supporting the plan of BTS (base transceiver stations) for mobile network in urban context. Transactions on Communications, 8.

Cata, T., Patel, P.S., \& Sakaguchi, T. (2013). QR code: A new opportunity for effective mobile marketing. Journal of Mobile Technologies, Knowledge and Society, 2013. DOI: 10.5171/2013.748267.

Chwałek, J. (2014). Kierunki innowacji w handlu. Handel Wewnętrzny, 2(349).

Coy, D.R. (2014). How technology and mobile devices are changing the way we shop. Obra Digital, 4. DOI: 10.25029/od.2013.10.4.

Deloitte. (2018). Retail 360 / Connected Stores: Transforming store fleet through technology. Retrieved from https://www2.deloitte.com/content/dam/Deloitte/dk/Documents/consumer-business/Downloads/ Connected_Stores_Deloitte.pdf [access: 5.01.2019]. 
Dubos-Le Cadre, Ch. (2016). Consumers' concerns around the issue of geolocation systems for mobile marketing. Dublin Business School.

Frant, T. (2018). Ewolucja, kierunki zmian i możliwe scenariusze rozwoju handlu detalicznego online. Marketing i Rynek, 4.

Fuchs, K., Vuckovac, D., \& Ilic, A. (2017). Towards Interoperability in Mobile Coupons: Enabling Cross Retailer Coupon Validation. Proceedings of the $8^{\text {th }}$ International Conference on ICT Convergence, IEEE, South Korea.

How to create one-time redeemable QR Code Coupons. (2018). Retrieved from https://qrd.by/how-tocreate-one-time-redeemable-qr-code-coupons [access: 11.01.2019].

Jang, Z. et al. (2016). ARTcode: Preserve Art and Code In Any Image. Proceedings of the 2016 ACM International Joint Conference on Pervasive and Ubiquitous Computing Heidelberg, Germany.

DOI: http://dx.doi.org/10.1145/2971648.2971733.

Kang, J.Y.M., Mun, J.M., \& Johnson, K.K.P. (2015). In-store mobile usage. Downloading and usage intention toward mobile location-based retail apps. Computers in Human Behavior, 46.

DOI: https://doi.org/10.1016/j.chb.2015.01.012.

Kern, A. (2018). The Importance of ICT in the Retail Industry. Fundamental Opportunities and Challenges in a Globalized World. Linz: Johannes Kepler University.

Kieżel, M., Reformat, B. (2015). Geolocation as a Marketing Innovation in Communications and the Conditions of its Use in the Polish Retail Sector and Retail Banking. Proceedings of the LCBR European Marketing Conference. Lupcon Center for Business Research, Lisbon.

DOI: 10.13140/RG.2.1.4321.9288.

Komosny, D. et al. (2017). Location accuracy of commercial IP address geolocation databases. Information Technology and Control, 46. DOI: 10.5755/j01.itc.46.3.14451.

Kucharska, B. (2013). Technologie informacyjne w handlu detalicznym. Studia Ekonomiczne, 150.

Malinowska, M. (2016). Innowacyjne formy komunikacji marketingowej w handlu - perspektywa konsumenta. Studia Ekonomiczne, 302.

Mazur, Z., \& Mazur, H. (2014). Systemy automatycznej identyfikacji - zastosowania i bezpieczeństwo danych. Wrocław: Politechnika Wrocławska.

McKinsey Global Institute. (2016). Raport Cyfrowi Polacy - konsumenci w czasach e-rewolucji. Warszawa: McKinsey.

Nowa aplikacja L'Oreal 'Makeup Genius' App. (2014). Retrieved from http://www.beautyadvisor. eu/2014/12/nowa-aplikacja-loreal-makeup-genius-app.html [access: 12.01.2019].

Notomi, N. (2015). ICT and the future of the retail industry - consumer-centric retailing. NEC Technical Journal, 10.

Pearson, B. (2016, 12 December). 7 under-the-radar retail trends for 2017. Forbes. Retrieved from https:// www.forbes.com/sites/bryanpearson/2016/12/28/7-under-the-radar-retail-trends-for-2017/ [access: 5.01.2019].

Plummer, L. (2018). Jak rzeczywistość wirtualna i rozszerzona odmieniaja zakupy? Retrieved from https:// www.intel.pl/content/www/pl/pl/it-managers/vr-ar-retail-experience.html [access: 5.01.2019].

Reformat, B. (2016). Information and communication technologies as a source of marketing innovations in retail - trends. Journal of Economics and Management, 23(1).

Reformat, B. (2017). Marketing Practices of Retail Chains Focussed on Changes in Eating Habits of Polish Consumers. Proceedings of the $17^{\text {th }}$ International Scientific Conference: Globalization and Its Socio-Economic Consequences, University of Zilina, Slovakia.

Rozpoczęła się kampania o zwiększenie mocy stacji bazowych polskich operatorów (2014, 8 October). Dziennik Gazeta Prawna. Retrieved from https://gsmonline.pl/artykuly/zwiekszenie-mocy-nadajnikow-stacje-bazowe [access: 30.12.2018].

Sławińska, M. (2016). Innowacje w handlu detalicznym - aspekty strategiczne. In: M. Sławińska (red.), Handel we współczesnej gospodarce. Nowe wyzwania. Poznań: Wydawnictwo Uniwersytetu Ekonomicznego. 
Pobrane z czasopisma Annales H - Oeconomia http://oeconomia.annales.umcs.pl Data: 26/04/2023 03:40:41

THE INCREASED IMPORTANCE OF GEOLOCATION IN RETAIL TRADE IN POLAND...

Su, M., Zheng, X., \& Sun, L. (2014). Coupon trading and its impacts on consumer purchase and firm profits. Journal of Retailing, 90. DOI: https://doi.org/10.1016/j.jretai.2013.06.004.

Taylor, D.G., \& Levin, M. (2014). Predicting mobile app usage for purchasing and information sharing. International Journal of Retail \& Distribution Management, 42. DOI: 10.1108/IJRDM-11-2012-0108.

Triukose, S. et al. (2012). Geolocating IP Addresses in Cellular Data Networks. International Conference on Passive and Active Network Measurement. Berlin-Heidelberg: Springer.

Wallace, B. (2018). Augmented reality's next frontier is business innovation. Retrieved from https://www. cmswire.com/digital-experience/augmented-realitys-next-frontier-is-business-innovation/ [access: 29.12.2018]. 